\title{
PEMBERDAYAAN POTENSI DESA TAPAK GEDUNG UNTUK MENINGKATKAN PRODUKSI AYAM ARAB
}

\author{
THE POTENTIAL EMPOWERMMENT OF TAPAK GEDUNG \\ VILLAGE IN INCREASING THE PRODUCTION OF ARAB CHICKEN
}

\author{
Oleh : \\ Dewi Handayani \\ Program Studi Pendidikan Kimia, FKIP Universitas Bengkulu, Bengkulu \\ Email:zidan1712@yahoo.com
}

\begin{abstract}
The purposes of the devotion activities are to provide the skill of the society in empowering the village potential for productifity of raising Arab chickens; to increase the production of Arab chickens by exploiting the natural resouces in Tapak Gedung village, the cage materials, the feed materials, and the available of human resources. Moreover, it can form a business unit that will be coordinated by a group of farmers to manage the production and product marketing of eggs, chicken meat, and chicken manure as a business for establising and develoving the independent and economically society. The method use in this devotion is by using extension activities, training, guided practice, and evaluation. In the extentsion phase, participants are given counseling about the potential of the village for raising chicken Arab. In the training and workshop phase, participants are given the material about the making of the cage, feed mabufacturing, chicken raising, and bussines development. In the direct and guided practice, participants are invited to make the cage, make the feed, and raise chickens until they can produce eggs, chicken manure, and chicken meat. Then, the product will be market and socialize to another village in Kepahiang district. From the result devotion, society has to understand how to make chicken cage and chicken feed, how to raise Arab chicken and a way of packaging and marketing of eggs Arab chickens. Societies are very enthusiastic and hope that this program can continue for the next years, and there is a serious coaching from the goverment, especially, the animal and husbandry department. The hope is there is funding from goverment for the development of larger business as efforts to improve the welfare of the society in the village.
\end{abstract}

Keywords: arab chicken eggs, arab chicken production

\section{PENDAHULUAN}

Tapak Gedung adalah salah satu desa di Kabupeten Kepahiang Provinsi Bengkulu. Desa Tapak Gedung merupakan salah satu desa tua di Kabupaten Kepahiang. Desa Tapak Gedung Kepahiang dipimpin oleh Kepala Desa Sutarwijaya. Desa ini dihuni oleh masyarakat Suku Serawai dengan mayoritas mata pencarian penduduknya petani dan peternak (90\%), $10 \%$ adalah Pegawai dan Pedagang. Tanaman pertanian penduduk adalah kopi. Ternak yang dipelihara adalah ayam kampung dan kambing. Baik pengelolaan pertanian dan ternak masih dikelola secara tradisional. 
Ayam arab berasal dari Belgia yang disebut dengan nama Brakel Kriel yang termasuk ke dalam galur ayam petelur unggul di Belgia. Ayam arab merupakan ayam lokal Indonesia pendatang yang merupakan hasil penetasan dari beberapa butir telur yang dibawa dari luar (Arab). Telur ayam arab pertama kali dibawa ke Indonesia dan ditetaskan menggunakan induk ayam kampung yang sedang mengeram. Anak ayam hasil penetasan ini dibesarkan dan diumbar di pekarangan rumah sehingga kawin dengan ayam lokal dan dinamakan ayam arab (Sarwono, 2001).

Dari hasil Observasi tim di desa Tapak Gedung, sangat bagus pengembangan ternak ayam arab (ayam petelur). Hal ini dikarenakan beberapa hal berikut ini :

1. Penduduknya masih jarang. Sebagian besar wilayahnya masih kebun, sawah dan hutan. Sehingga tidak mengganggu masyarakat sekitar jika dijadikan sentra ternak ayam arab.

2. Ketersediaan pakan ayam berupa jagung dan dedak sangat banyak dan harga tergolong murah karena penduduk juga sebagai petani jagung dan padi (bahan utama pakan ayam arab selain kosentrat).

3. Ketersediaan bahan kandang ayam sangat banyak berupa bambu dan kayu. Harga bambu dan kayu masih murah bahkan gratis.

4. Sumber daya manusia masih banyak pengangguran, sehingga dapat dipekerjakan sebagai tenaga kerja.

Pakan untuk ayam yang baik apabila mengandung protein $17 \%$ dan energinya 2850 $\mathrm{kkal} / \mathrm{kg}$. Menurut Kholis dan Sitanggang (2002) kadar protein 16\% sudah mencukupi produksi telur untuk ayam Arab yang berumur lebih dari 18 minggu. Gunawan (2002) melaporkan dengan kandang baterai dan ransum berprotein 15\% dan ME $2500 \mathrm{kkal} / \mathrm{kg}$, produksi telur mencapai 48,5\%. Sedangkan menurut Tajufri (2013) protein 17\% dan energi $2700 \mathrm{kkal} / \mathrm{kg}$ menghasilkan produksi dan berat telur paling tinggi dibandingkan protein 14\%-16\% dan energi $2400 \mathrm{kkal} / \mathrm{kg}, 2600 \mathrm{kkal} / \mathrm{kg}, 2700 \mathrm{kkal} / \mathrm{kg}$. Sugandhi (1973) menyatakan bahwa meningkatnya kandungan protein dengan kandungan energi yang sama dapat meningkatkan produksi telur. Sehingga dalam kegiatan pengabdian ini, komposisi pakan ayam arab sangat diperhatikan.

Selain potensi desa yang sangat baik untuk beternak, ternyata diwilayah Kepahiang masih kekurangan produksi telur jika dibandingkan dengan permintaan. Hal ini dibuktikannya dengan pedagang telur di Kepahiang masih membeli telur dari Kota Lubuk Linggau dan Padang.

Di Kabupaten Kepahiang belum ada peternak ayam arab. Sehingga berternak ayam arab di Tapak Gedung Kepahiang masih sangat potensial, baik untuk konsumsi keluarga dan lebih-lebih lagi untuk pengembangan usaha.

Jika kita survey di pasar, karena semakin sadarnya masyarakat akan nilai gizi telur, masih banyak pembeli telur yang bertanya keberadaan telur ayam kampung/ayam arab, namun ketersediaannya yang terbatas (habis). Potensi konsumen masih sangat banyak, misalnya pedagang jamu baik di depot jamu maupun penjual jamu keliling. Selain itu, ketersediaan telur ayam kampung atau ayam arab juga banyak ditanyakan diwarung- 
warung kecil di pasar atau di pedesaan. Telur ayam kampung/arab dijadikan untuk obat dan penambah stamina bagi pekerja dan petani, sehingga banyak diminati di masyarakat Kepahiang. Jadi penyaluran hasil produksi telur masih terbuka lebar.

Tabel 1. Harga telur di wilayah Kepahiang (Februari, 2015)

\begin{tabular}{cc}
\hline Nama Telur & Harga satuan (Tergantung volume) \\
\hline Ayam Arab & Rp 2.000-Rp 2.500 \\
Ayam Ras & Rp 1.200-Rp 1.500 \\
\hline
\end{tabular}

Selama ini mayoritas masyarakat hanya menggantungkan ekonomi pada hasil panen kopi setahun sekali. Sehingga pada saat belum musim kopi, masyarakat di desa Tapak Gedung menjadi pengangguran dan cenderung melakukan hal yang tidak produktif bahkan negatif. Jika dilihat dari dampak kurangnya aktifitas masyarakat, banyak pemuda-pemudi di Desa Tapak Gedung yang pengangguran. Dampak pengangguran dan kemiskinan cukup besar di desa Tapak gedung, diantaranya : kawin usia muda, pencurian, berkelahi, berjudi, sabung ayam, dan lain sebagainya. Tingkat pendidikan masyarakat tergolong rendah, masih banyak masyarakat yang tidak taman SMP dan masih ada yang belum tamat SD.

Dari tabel di atas, potensi pendapatan harian jika tersedia induk ayam arab 100 ekor adalah Rp 250.000 / hari. Kondisi ini sangat membantu ekonomi masyarakat di Tapak Gedung. Sehingga dengan adanya ternak ayam arab, akan menimbulkan pekerjaan yang positif sekaligus produktif dalam bidang ekonomi kemasyarakatan.

Mengingat betapa starategisnya pengembangan ternak ayam arab di Desa Tapak Gedung Kepahiang, tim Iptek bagi Masyarakat (IbM) tahun 2015 mengusulkan kegiatan Pemberdayaan Potensi Desa Tapak Gedung untuk Meningkatkan Produksi Ayam Arab. Mitra dalam kegiatan ini adalah 2 kelompok tani yang terdiri dari minimal 20 orang per kelompok tani di Tapak Gedung. Nama kelompok Tani yang ada di Desa Tapak Gedung diantaranya adalah Kelompok Tani Serasan dan Kelompok Tani Seijoan.

Secara garis besar permasalahan mitra adalah : 1) Belum menyadari bahwa potensi usaha yang ada di desa sangat besar, 2) kekurangan informasi terkait pengembangan potensi desa, 3) belum adanya skil yang baik dalam mengolah potensi desa, 4) banyak pengangguran karena tidak ada penyaluran potensi diri, 5) ekonomi dan pendidikan masyarakat masih tergolong rendah. Pengusul bersama dengan tim ahli sudah melakukan koordinasi ke beberapa praktisi peternak ayam arab yang menunjukkan bahwa dengan beternak ayam arab dengan benar akan menghasilkan keuantungan yang berlipat. Selanjutnya pengusul sudah berkoordinasi dengan mitra dan sepakat untuk bekerja sama menyelesaikan permasalahan diatas dengan surat kesepakatan. Dari hasil kegiatan ini target yang akan dihasilkan adalah :

1. Masyarakat/mitra memahami terkait dengan penggalian, memanfaatkan, dan mengembangkan potensi desa yang dapat menunjang usaha peternakan ayam arab.

2. Masyarakat/mitra mengetahui dan dapat melakukan tahapan pemeliharaan ayam arab, mulai dari memperoleh bibit, pembuatan kandang, pemeliharaan, produksi dan 
pemasaran hasil. Semua tahapan akan lebih muda dengan memanfaatkan potensi yang dimiliki desa.

3. Masyarakat/mitra dapat membuat pakan, dengan bahan yang tersedia dari hasil pertanian Desa Tapak gedung.

4. Masyarakat/mitra dapat mengembangkan potensi usaha lain dari peternakan ayam arab. Misalnya pengolahan kotoran menjadi pupuk, pembuatan pakan ternak, dan pembibitan dengan mesin tetas sederhana.

5. Masyarakat/mitra mengetahui jalur pengembangan usaha yang lebih besar melalui bermitra dengan pihak lain (penyandang dana).

Selanjutnya dengan tercapainya usaha ini diharapkan mitra mampu menjadi pengusaha ayam arab secara berkelanjutan, sehingga masyarakat akan meningkat secara ekonomi, membuka peluang kerja, dan akan mengatasi permasalahan yang ada khususnya di desa Tapak Gedung Kepahiang.

\section{METODE PENGABDIAN}

Kegiatan Pengabdian ini dilaksanakan di Desa Tapak Gedung, dengan sasaran 2 Kelompok Tani yaitu Kelompok Tani Serasan dan Seijoan masing-masing 20 orang per kelompok. Kegiatan dilaksanakan pada bulan Mei - November 2016. Solusi yang ditawarkan dalam usulan ini adalah untuk mengatasi permasalahan yang terjadi pada masyarakat desa Tapak Gedung, yaitu dengan menggunakan tiga metode pendekatan. Penyuluhan, Pelatihan/workshop, dan praktek terbimbing serta evaluasi. Beberapa metode yang digunakan adalah sebagai berikut:

\section{A. Penyuluhan}

Pada tahap ini, mitra (peserta) diberikan penyuluhan tentang:

1. Potensi lingkungan yang mendukung peternak ayam arab: lahan yang luas, ketersediaan bambu dan kayu untuk kandang, ketersediaan jagung dan dedak sebagai pakan.

2. Potensi tenaga kerja yang besar.

3. Potensi usaha yang menjanjikan.

Kegiatan penyuluhan ini dilakukan selama 1 hari, bertempat di rumah Kepala Desa Tapak Gedung.

B. Pelatihan dan workshop

Materi tentang Pemberdayaan Potensi Desa Tapak Gedung untuk Meningkatkan Produksi Ayam Arab adalah:

1. Pembibitan atau cara mendapatkan bibit ayam arab (semua umur) dari DOC sampai umur siap telur.

2. Pembuatan Kandang.

3. Pembuatan dan cara pemberian pakan. 
4. Cara pemeliharaan disetiap tahapan umur.

5. Penyakit dan pencegahannya.

6. Pemasaran produk telur, daging ayam afkir, pupuk.

7. Analisis usaha dan pengembangannya.

8. Praktek Langsung pembuatan kandang dan pakan secara terbimbing.

Tahap ini dilakukan selama 7 hari, 2 hari materi konseptual dan 5 hari praktek. Pembuatan kandang dan pakan ini langsung di bimbing tim IbM Dikti dan langsung diikuti/dipraktekkan oleh peserta. Tempat menyampaikan materi dan praktek adalah di rumah Kepala Desa Tapak Gedung.

\section{Pengerjaan Produk mandiri dengan Bimbingan}

Pada tahapan ini, 2 Kelompok tani (peserta) Serasan dan Seijoan akan bekerja pada lokasi yang berbeda, sehingga sentra produksi terdapat 2 lokasi. Dua sentra inilah nanti cikal bakal peternakan ayam arab di desa Tapak Gedung. Cikal bakal peternakan ini akan diarahkan dan dibimbing oleh tim IbM DIKTI untuk membuat produk yang lebih baik dan berkualitas. Selama proses pengerjaan terbimbing ini diharapkan terjadi saling transfer kemampuan antar anggota kelompok. Pada tahap ini tim fasilitator (pengusul) siap memberikan bimbingan bagi peserta yang mengalami kendala dalam pembuatan. Pada tahap sudah mahir dan telah siap memasukkan ayam arab, pemeliharaan, dan produksi telur; tim IbM akan memfokuskan pembinaan pada analisis usaha dan lain-lain. Gunanya adalah untuk tambahan penghasilan dan meningkatkan kesejahteraan masyarakat.

D. Monitoring dan evaluasi kerja kelompok Tani

\section{HASIL DAN PEMBAHASAN}

Kegiatan Pengabdian dilakukan di Desa Tapak Gedung Kabupaten Kepahiang. Persiapan awal yang dilakukan adalah persiapan alat dan bahan, ruangan, perlengkapan di lapangan dan lain-lain. Persiapan alat dan bahan dilakukan pada bulan Mei- Juni 2016. Sudah dibuat panduan pembuatan kandang ayam, pakan ternak dan cara pemeliharaan ayam arab. Koordinasi dengan kepala desa dan kelompok tani sudah dilakukan. 2 Kelompok Tani Serasan dan Seijoan juga sudah menyiapkan bambu dan sekam sebagai salah satu bahan pembuatan kandang ayam dan pakan ternak. Lokasi pembuatan/ pengolahan kandang ayam dan pakan ternak sudah disiapkan di salah satu rumah anggota kelompok tani. 

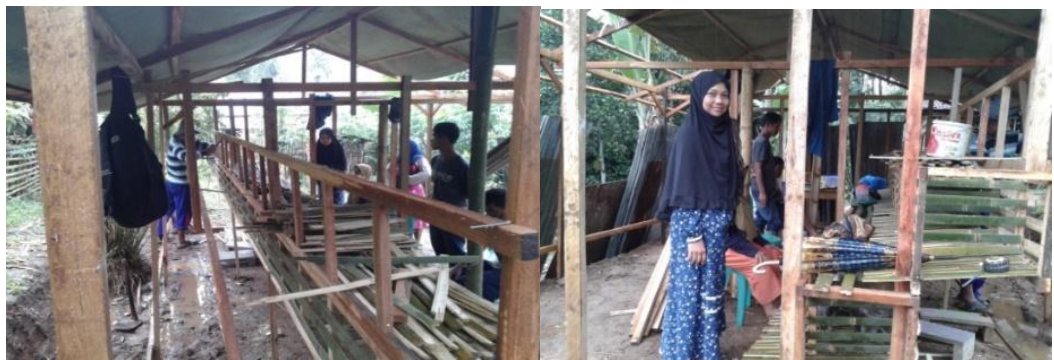

Gambar 1. Proses pembuatan kandang ayam

Metode yang digunakan dengan tiga metode pendekatan yaitu penyuluhan, pelatihan/workshop, praktek terbimbing, dan evaluasi. Pada tahap pertama yaitu kegiatan penyuluhan sudah dilakukan, petani (peserta) diberikan penyuluhan tentang potensi lingkungan yang mendukung peternak ayam arab: lahan yang luas, ketersediaan bambu dan kayu untuk kandang, ketersediaan jagung dan dedak sebagai pakan. Potensi tenaga kerja yang besar dan potensi usaha yang menjanjikan. Kegiatan penyuluhan ini dilakukan selama 1 hari, bertempat di rumah Kepala Desa Tapak Gedung.
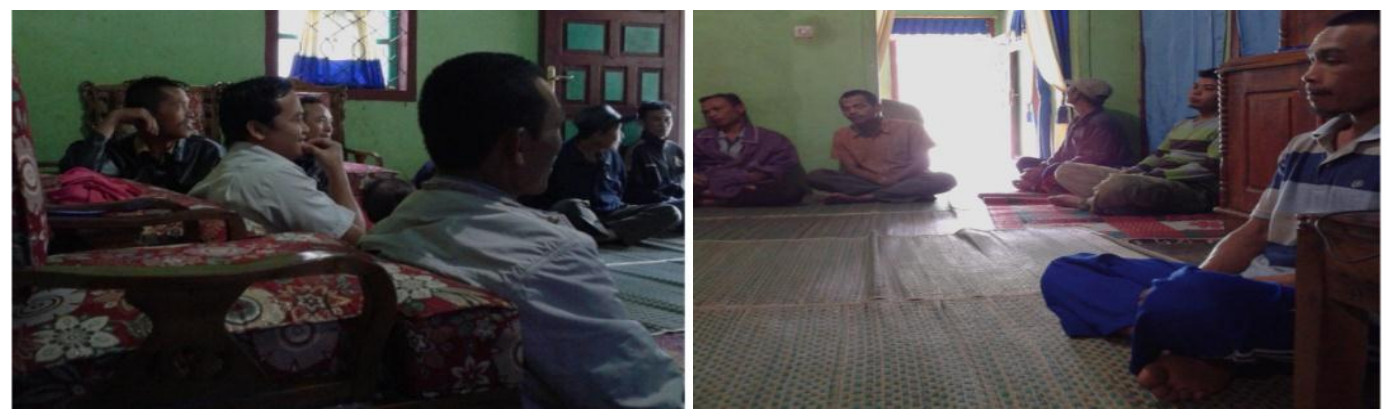

Gambar 2. Kegiatan Penyuluhan

Setelah kegiatan penyuluhan selesai, dilakukan kegiatan pelatihan dan workshop. Pada tahap ini, masyarakat/ peserta pelatihan diberi materi tentang pemberdayaan potensi desa tapak gedung untuk meningkatkan produksi ayam arab, diantaranya adalah:

1. Pembibitan atau cara mendapatkan bibit ayam arab (semua umur) dari DOC sampai umur siap telur.

2. Pembuatan Kandang.

3. Pembuatan dan cara pemberian pakan.

4. Cara pemeliharaan disetiap tahapan umur.

5. Penyakit dan pencegahannya.

6. Pemasaran produk telur, daging ayam afkir, pupuk.

7. Analisis usaha dan pengembangannya.

8. Praktek langsung pembuatan kandang dan pakan secara terbimbing.

Tahap ini dilakukan selama 7 hari, 2 hari materi konseptual dan 5 hari praktek. Penyampaian materi pelatihan dan praktek kegiatan pengabdian ini mulai tanggal 18-19 Juli 2016. Pembuatan kandang dan pakan ini langsung di bimbing tim IbM Dikti dan 
langsung diikuti/dipraktekkan oleh peserta. Tempat menyampaikan materi dan praktek di rumah Kepala Desa Tapak Gedung Kepahiang.

Kandang ayam yang di buat adalah kandang terbuka tanpa dinding. Arah kandang adalah arah Utara ke Selatan agar kandang mendapatkan sinar matahari pagi dan sore. Kandang utama berukuran $5 \times 15$ meter dengan tinggi sekitar $3.5 \mathrm{~m}$. Masing-masing ayam dimasukkan dalam kandang baterai, dengan ukuran kandang baterai adalah:

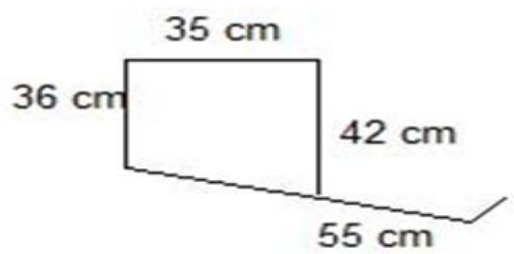

Gambar 3. Ukuran Kandang

Panjang kandang baterai adalah $110 \mathrm{~cm}$ yang dibagi menjadi 4 ruangan yang sama luas. Masing-masing kandang baterai dapat memuat maksimal 2 ekor ayam layer yang siap bertelur (Sudaryani, 2000). Bibit ayam arab diperoleh dari Kota Bengkulu yaitu ayam yang siap bertelur. Untuk cara pemeliharaan dan pembuatan pakan ternak ayam arab mengikuti panduan yang sudah di berikan kepada dua kelompok tani.

Tahap berikutnya adalah pengerjaan produk mandiri dengan bimbingan. Pada tahapan ini, 2 Kelompok tani (peserta) Serasan dan Seijoan akan bekerja pada lokasi yang berbeda, sehingga sentra produksi terdapat 2 lokasi. Dua sentra inilah nanti cikal bakal peternakan ayam arab di desa Tapak Gedung. Cikal bakal peternakan ini akan diarahkan dan dibimbing oleh tim IbM DIKTI untuk membuat produk yang lebih baidk dan berkualitas. Selama proses pengerjaan terbimbing ini diharapkan terjadi saling transfer kemampuan antar anggota kelompok. Pada tahap ini tim fasilitator (pengusul) siap memberikan bimbingan bagi peserta yang mengalami kendala dalam pembuatan.

Pada tahap sudah mahir dan telah siap memasukkan ayam arab, pemeliharaan, dan produksi telur; tim IbM akan memfokuskan pembinaan pada analisis usaha dan lain-lain. Gunanya adalah untuk tambahan penghasilan dan meningkatkan kesejahteraan masyarakat.

Hasil yang diperoleh dalam usaha ternak ayam arab ini selain telur diantaranya adalah pupuk kandang yang diperoleh dan di olah dari kotoran ternak ayam arab, ayam afkir dan masyarakat juga bisa mengembangkan usahanya sendiri dengan memulai pembibitan sendiri dengan menggunakan mesin tetas yang di modifikasi sendiri. Untuk pemasaran telur bekerjasama dengan pedagang di Pasar Kepahiang dan ada yang di jual secara langsung ke konsumen. 


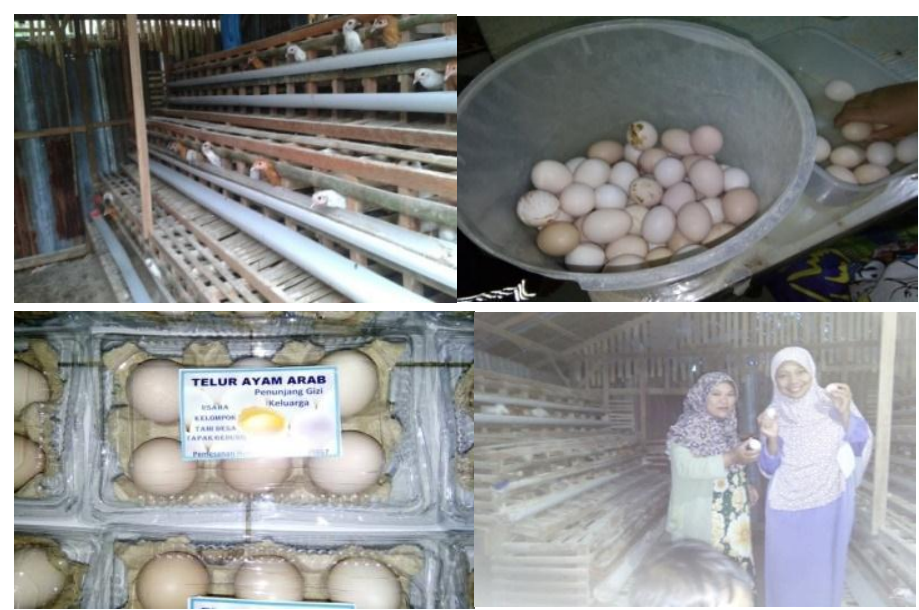

Gambar 4. Produk yang dihasilkan

Tahap selanjutnya adalah monitoring dan evaluasi. Monitoring dilaksanakan untuk melihat keberhasilan kegiatan setelah beberapa tahapan di atas dilaksanakan terutama setelah tahap pengerjaan kelompok dilakukan. Tim IbM DIKTI telah membuat instrumen untuk mengevaluasi berbagai produk yang dibuat/dikerjakan oleh masing-masing kelompok cikal bakal peternakan ayam arab di Desa Tapak Gedung Kepahiang.

Selanjutnya akan dipilih produk-produk yang terbaik sehingga dapat dijadikan sampel/model yang layak dicontoh untuk di produksi lebih lanjut. Sementara ada hal yang belum baik, akan diberikan masukan-masukan dari tim IbM DIKTI untuk disempurnakan lebih lanjut. Dari hasil monitoring dan evaluasi yang telah dilakukan oleh Tim Pengabdian, masyarakat telah memahami tentang cara pembuatan kandang ayam arab, pembuatan pakan ternak untuk ayam arab, cara memelihara ayam arab serta cara pengemasan dan pemasaran telur ayam arab. Masyarakat sangat antusias dan berharap program ini bisa terus berlanjut untuk tahun-tahun berikutnya serta ada pembinaan yang serius juga dari pemerintah terutama Dinas Peternakan. Harapannya ada bantuan dana juga dari pemerintah untuk pengembangan usaha yang lebih besar sebagai upaya penungkatan kesejahteraan masyarakat Desa.

\section{Sosialisasi/Pemasaran untuk Wilayah Lokal}

Produk yang sudah dahasilkan berupa telur, ayam afkir, pupuk; akan dipromosikan di rumah ketua kelompok tani yang memungkinkan dan akan dibuat pelang Merk "Tersedia Telur Ayam".

Desa Tapak Gedung juga mempunyai tempat wisata provinsi Bengkulu, yaitu Air Terjun "Curug Embun" yang sering dikunjungi wisatawan dari seluruh warga Provinsi Bengkulu bahkan dari luar Provinsi. Oleh karena itu produk hasil peternakan akan dipajang di rumah warga depan pintu gerbang Wisata Air Terjun Curug Embun, sekaligus tulisan-tulisan promosi. Pengunjung dapat melihat dan mengenal produk Pupuk Organik dan Pakan Ternak masyarakat Desa Tapak Gedung dan memungkinkan membeli. Peternak 
juga mesti melakukan survey konsumen di warung-warung, pasar, tukang jamu, atau jika memungkinkan ke daerah lain yang membutuhkan telur ayam arab.

Produk hasil peternakan Tapak Gedung dapat dipromosikan lewat media elektronik, media cetak, bazar/pameran produk pertanian, seminar, dan dari mulut ke mulut. Beberapa keunggulan ayam Arab antara lain (1) potensi produksi telurnya mencapai 50-60\% lebih banyak dibanding ayam kampung, (2) konversi pakan rendah, (3) pejantan Arab mempunyai keunggulan mampu mengawini ayam betina setiap 2-3 jam, (4) relatif lebih tahan penyakit, dan. (5) dapat dipelihara dengan pola tradisional sampai intensif (Yulianto, 2000). Ayam Arab merupakan ayam petelur unggul yang digolongkan ke dalam ayam tipe

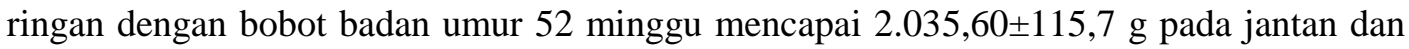
$1.324,70 \pm 106,47 \mathrm{~g}$ pada betina (Nataamijaya dkk, 2003). Ayam arab umumnya memiliki ketahanan tubuh yang kuat terhadap penyakit. Penggunaan obat-obat kimia untuk ayam arab petelur juga relatif lebih sedikit. Hal ini yang menyebabkan banyak orang yang mengkonsumsi telur ayam arab karena lebih alami. Telur ayam arab memiliki rasa yang lebih gurih dan kadar keamisannya lebih rendah. Oleh karena itu, telur ayam arab tidak hanya dikonsumsi matang, tetapi sering juga dikonsumsi mentah sebagai campuran madu, susu, atau jamu dengan dalil untuk menambah vitalitas atau kebugaran tubuh. Telur ayam arab juga banyak digunakan sebagai obat dan kosmetik (Linawati, 2009).

Evaluasi yang dilakukan untuk menilai keberhasilan kegiatan pengabdian ini adalah dengan cara:

1. Melihat respon dan antusias mitra/masyarakat terhadap peternakan ayam arab terhadap dampak peningkatan ekonomi.

2. Memonitor setiap tahapan apakah sesuai dengan panduan.

3. Monitoring hasil kegiatan berupa produknya. Serta melihat peternakan tersebut dalam kaitannya dengan kesejahteraan di bidang ekonomi, kegiatan positif, dan kreasi masyarakat.

\section{KESIMPULAN DAN SARAN}

Dari kegiatan pengabdian ini maka dapat disimpulkan bahwa sebagian besar masyarakat desa Tapak Gedung sudah mengetahui arti pentingnya potensi desa yang dapat menunjang usaha peternakan ayam arab. Masyarakat memperoleh pengetahuan (knowledge) dan keahlian (skill) tentang tahapan pemeliharaan ayam arab, mulai dari memperoleh bibit, pembuatan kandang, pemeliharaan, produksi dan pemasaran hasil.

Adapun saran dari pelaksanaan pengabdian ini adalah hendaknya Pihak pemerintah daerah memfasilitasi secara berkelanjutan pengembangan produksi ayam arab sehingga dapat dikembangkan untuk skala industri. Melihat respon dan hasil yang baik yang ditunjukkan oleh masyarakat Desa Tapak Gedung Kabupaten Kepahiang, maka sebaiknya program ini dilaksanakan juga untuk daerah lain di propinsi Bengkulu. 


\section{DAFTAR PUSTAKA}

Amrullah, I. K, 2003, Nutrisi Ayam Petelur, Lembaga Satu Gunungbudi, Bogor.

Abbas, M.H, 1999, Pengelolaan Ternak Unggas, Program Pasca Sarjana Universitas Andalas, Padang.

Anggorodi, H. R, 1995, Nutrisi Aneka Ternak Unggas, Universitas Indonesia Press, Jakarta.

Gunawan, 2002, Evaluasi model pengembangan usaha ternak ayam buras dan upaya perbaikannya (Kasus di Jawa Timur) (Disertasi), Program Pascasarjana Institut Pertanian Bogor, Bogor.

Kholis, S., M. Sitanggang, 2002, Ayam Arab dan Poncin Petelur Unggu, PT. Agro Media Pustaka, Jakarta.

Linawati, 2009, Formulasi Strategi Pengembangan Usaha Ayam Arab Petelur di Trias Farm Kabupaten Bogor, Institut Pertanian Bogor, Bogor.

Nataamijaya. A.G., A.R. Setioko, B. Brahmantiyo dan K. Diwyanto, 2003, Performans dan Karakteristik Tiga Galur Ayam Lokal (Pelung, Arab, dan Sentul), Prosiding Seminar Nasional Teknologi Peternakan dan Veteriner.

Sarwono, B, 2001, Ayam Arab Petelur Unggul, Penebar Swadaya, Jakarta.

Sudaryani, T., H. Santoso, 2000, Pemeliharaan Ayam Ras Petelur di Kandang Baterai, Penebar Swadaya, Jakarta.

Sugandhi, D., 1973, The Effect of Different Energy and Protein Level on The Performance of Laying Hens in Floor Pens and Cages in The Tropics, Disertation, Bogor Agriculture University, Bogor.

Warwick, E. J., J.M. Astuti, dan W. Hardjosubroto, 1990, Pemuliaan Ternak, Gadjah Mada University Press, Yogyakarta. , 2015, "Sumber ONLINE". 